\title{
THE IMPACT OF COVID-19 ON THE PERFORMANCE OF INTERNATIONAL COMMERCIAL CONTRACTS FOR THE SALE OF GOODS - FORCE MAJEURE AND HARDSHIP
}

\author{
Ljuben Kocev LL.M. \\ Faculty of Economics - Skopje, Ss. Cyril and Methodius University \\ ljuben.kocev@eccf.ukim.edu.mk
}

\begin{abstract}
The outbreak of COVID-19 has had massive negative impact across all industries and fields in the entire world. While the negative health impact is slowly stabilizing, the economic impact is in full effect and the harm is yet to be evaluated. On macroeconomic level, the necessary measures for combating the pandemic which were undertaken by governments have significantly restricted international trade. On microeconomic level, merchants and businesses are faced with inability or extreme obstacles in their daily operations and particularly in performing their international sales contracts. Failure to perform results in contractual breach and unwanted claims for damages.

The paper addresses the impact which COVID-19 has on the performance of international commercial contracts for the sale of goods. The paper considers the impediments which may arise due to the pandemic outbreak and evaluates them from a legal perspective under the UN Convention on Contracts for the International Sale of Goods from 1980 (CISG), which is the main legal instrument governing international sales contracts. Particularly, the paper focuses on the question of exemption from liability in a situation where either of the contractual parties fails to perform and breaches an obligation. The evaluation is conducted through interpretation of the concepts of force majeure and hardship, as grounds for non-performance or contract renegotiation in light of the current situation.
\end{abstract}

Keywords: Covid-19, CISG, Hardship, Force Majeure, Exemption of Liability

JEL classification: F10, K12, K33

\section{INTRODUCTION}

The international sale of goods is performed in a complex environment composed of numerous domestic and international regulations and standards, and in a form of web of arrangements among traders in the supply chain. In such a complex system, predictability is key factor. However, unexpected events can occur which can disrupt the normal course of business. The nature of the events can vary, ranging from natural disasters, wars and conflicts, riots, pandemics all the way to governmental actions and sanctions. More often than not these events are non-business related and outside of the sphere of control of the contracting parties. The manifestation of these types of events also makes the performance of the contract either impossible or significantly more difficult for one or both of the contracting parties.

The outburst of COVID-19, the virus which was first identified in Wuhan in December 2019, has transformed into a humanitarian crisis on a global scale. On $11^{\text {th }}$ of March 2020, WHO proclaimed pandemic on a global scale (www.who.int). The virus has affected all aspects of society and all industries are facing turmoil. COVID-19 is upending normal life around the world, and with it, hindering the performance of many commercial contracts. On global scale the international exchange of goods has been in steady decline. According to the WTO, world trade is expected to fall between 13\% and 32\% in 2020 as a result of COVID-19 (Figure 1). 
Figure 1: World merchandise trade volume 2000-2022

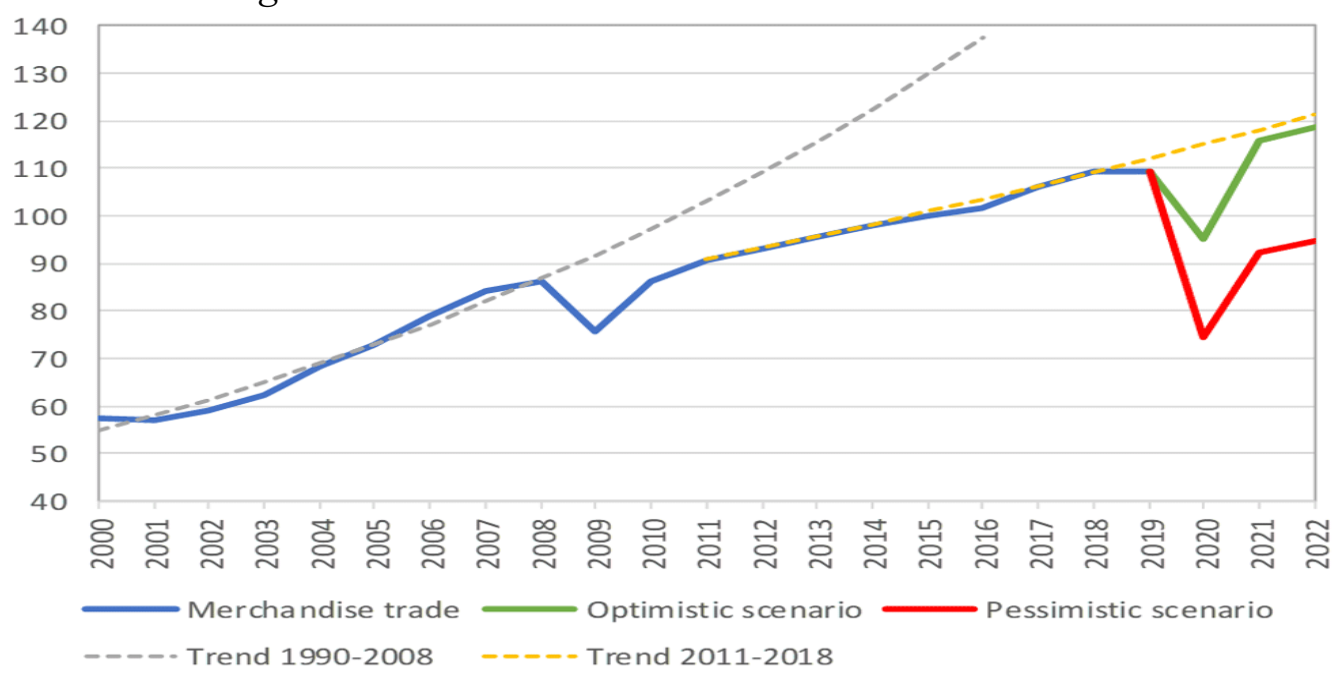

(Source: WTO secretariat)

Similarly, reports from the OECD show disruption in global supply chains, indicated from the sharp drop in volume of air and sea cargo (Figure 2).

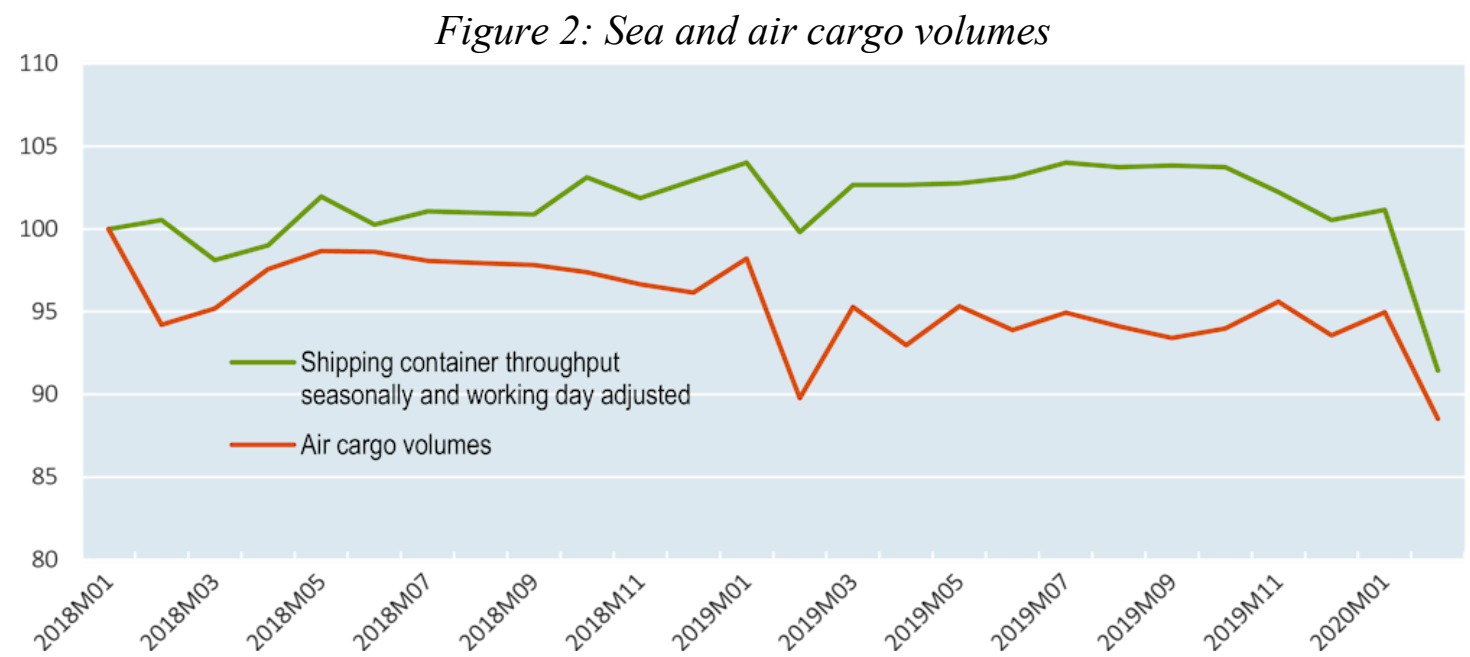

(Source: OECD, drawing on data from Innovative Solutions in Maritime Logistics (www.isl.org/en/containerindex) and International Air Transport Association (www.iata.org))

The state of play on macroeconomic level is the result of the set of actions taken at microeconomic level. With borders and factories being closed, and people staying at home for several months, most international commercial relationships have been, and will be affected further down the line. Consequently, the need for contractual and statutory remedies will be increasing. In anticipation of the aftermath, domestic courts and arbitral institutions have yet to witness an array of international commercial disputes. In light of this, merchants and businesses suspecting their incapability of compliance with the contractual obligations, or doubting the ability of the opposing contracting party, should consider and evaluate the options which they have within their contracts and the applicable law in the face of non-compliance. The article offers guideance on how business parties should approach their contractual relationships, asses (non)performance of the contractual terms in light of the current situation and evaluate the available options in consideration of the applicable law. The key focus is on 
the question whether the parties can be exempted from liability in potential default of their contractual obligations due to COVID-19, under the regime of the United Nations Convention on Contracts for the International Sale of Goods (CISG). The question of exemption of liability is evaluated through the analysis of two broadly recognized concepts in international commercial law - force majeure and hardship.

\section{ASSESMENT OF THE CONTRACTUAL RELATIONSHIP}

When assessing the possible options, the starting point is always to take into consideration the contract of the parties. In international commerce, the parties have the widest discretion and freedom to regulate their business relationship as they deem appropriate. According to the principle of party autonomy, aside from the essential contractual elements, the parties are free to incorporate in their contract, among others provisions, the applicable law, dispute resolution mechanisms, penalty clauses for breach of obligations, limitation of liability clauses etc. Depending of the size of the business, the geographical area, as well as the industry in which the company operates, it is very common for the parties to have standard for inclusion of limitation liability clauses in their contracts. These clauses usually encompass events which make contract performance either impossible (e.g. force majeure events) or more onerous (e.g hardship events) for either of the parties. The occurrence of the event would either exempt the parties from liability for non-performance, or would oblige the parties to renegotiate the contract and agree on more favorable terms. Many prominent institutions such as the ICC have their own versions or templates of such clauses (www.iccwbo.org), which the parties can accept in their contracts as drafted by the institutions, or have them modified in a way which they find suitable. If the parties have incorporated limitation of liability clause, then this would be the basis for assessment whether either of the parties can default on an obligation without being liable for damages, or can request renegotiation of the contract.

Alternatively, even if the contract does not specifically contain limitation of liability clause, it can nevertheless be incorporated through the standard terms and conditions of either of the contracting parties. Usually business parties have pre-drafted standards terms and conditions regulating issues which they consider to be important in the form of a boilerplate clauses. The standard terms can be incorporated in the contract, either explicitly, through their referral in the contract, or implicitly through the communication of the parties and exchange of offers and acceptance.

In absence of limitation of liability clause, the relevant question is whether the parties have chosen the applicable law for their contractual relationship. The choice of law clause determines the set of rules on which the legal evaluation of the contractual relationship would be performed. The incorporation of these clauses offers predictability to the parties and excludes the rather "uncertain" application of the conflict of law rules. It is important that the choice of a law of a country leads to application of its domestic law, but also to the international treaties and conventions which that country has signed and ratified as well (Lookofsky, 2012). One of the most significant instruments regulating international sale of goods is the United Nations Conventions on Contracts for the International Sale of Goods from 1980 (hereafter CISG). The CISG regulates several aspects of international sale of goods, but it focuses primarily on contract formation and performance. There are a number of ways in which the CISG can be applicable. Firstly, it will apply if the parties have explicitly chosen it to govern their contractual relationship. Secondly, the CISG would be applicable if the parties have not explicitly chosen it, but they have selected the law of a CISG contracting state. Thirdly, the CISG can be applicable even if the parties have not made any choice of law, but both parties have their place of business in CISG contracting states. Lastly, the CISG can be applicable if the rules of private international law lead to the application of a CISG contracting state. Given the number of ways in which the CISG can be applied, as well as the fact that to this date it is 
in force in 91 states worldwide (www.uncitral.un.org), a large number of international contracts for the sale of goods are subjected to its regime, and there is a high likelihood that disputes for failure to perform as a result of COVID-19 pandemic would have to be assessed in light of its provisions.

When assessing exemption of liability within the CISG, article 79 provides guidance. Article 79(1) has three prerequisites which need to be met in order for a party to be exempted from liability for non-performance: firstly, there must be an impediment hindering the contract performance which is beyond the control of the party claiming exemption, secondly, that it could not have been reasonable to expect that the party could have taken the impediment into account at the time of the conclusion of the contract, and thirdly, it could not be reasonably expected that the party could have avoided or overcome the impediment or its consequences (Schwenzer \& Schlechtriem, 2010). These prerequisites have to be met cumulatively. However, as evident from the text, the CISG does not contain possible scenarios which might be characterized as impediments, it does not contain references to hardship or force majeure, and for the matter of fact it does not even contain guidance of what is an "impediment".

The CISG contains unique and innovative concepts which had to be incorporated and drafted in such a manner in order to be freed from preconceived notions of concepts which already exist in various national laws (Kocev, 2018). The downside of this is that many of the innovative concepts and terms are vague and thereby require careful assessment and interpretation. In line with this, it is necessary to consider whether the current pandemic, caused by COVID-19 can be qualified as force majeure or hardship event, and whether either of these concepts is recognized and can fall within article 79 CISG.

\section{FORCE MAJEURE}

Force majeure has its roots in French law dating from the Civil Code of Napoleon. Force majeure or vis major is an event which is beyond the control the parties, and prevents one or both parties from performing their contractual obligations. The event must be of extraordinary nature and one which is unforeseeable and unavoidable (www.law.cornell.edu). It is important to note that at international level, there isn't a unified concept of force majeure, due to the fact that there are differences in national legislation. Nevertheless, certain general characteristics of the concept can be determined.

In international transactions force majeure generally refers to maters such as Acts of God, natural disasters, labor disputes and strikes, adverse governmental actions, expropriation, war or civil upheaval (Klotz \& Barrett, 2008). For example, the ICC force majeure clause (www.iccwbo.org) contains extensive list of events which can be considered as force majeure which among other encompass: wars, invasions, extensive military mobilization, riots rebellions and revolutions, acts of terrorism, currency and trade restrictions, embargos, acts of authorities (lawful and unlawful), expropriation and nationalization, plagues, epidemics, natural disasters, explosions, fires, break-down of transport, labor disturbances such as strikes and boycotts etc.

Regardless of the difference in origin, magnitude and to some extend duration of these events, what is common is that they make contractual obligations for one or both contracting parties incapable of being performed. These events make the contract performance objectively impossible, either because the goods have been destroyed (e.g. fire, flood), because one of the parties is unable to conduct its business in usual manner (strikes, boycotts, wars, terrorist attacks), the transport has become impossible (embargoes, transport break-downs, earthquakes) or maybe due to a combination of several events. The result of the occurrence of a force majeure event is that the contract would most likely have to be terminated, or in rare scenarios suspended (Rimke, 1999). From the perspective of the defaulting party, this would 
mean that it is not liable for the damage which has occurred (CISG Advisory Council Opinion No. 7, 2007).

However, the mere occurrence of a force majeure event would not exempt the breaching party from liability by default. Firstly, the event must occur after the conclusion of the contract. If the event has occurred prior, it is reasonable to believe that both parties had knowledge, and accepted the situation as such. Secondly, the event must occur prior to the expiration of the date for performance. For example, if the delivery of goods is due until the $10^{\text {th }}$ of the month, but the force majeure event materializes on the $20^{\text {th }}$, the seller cannot claim exemption of liability since he was already in breach of his delivery obligation, and had he performed on time he would have avoided the consequences.

As already noted, the CISG does not provide explicitly that force majeure events exempt the breaching party from liability. While it is generally accepted that force majeure events fall within the scope of the CISG, both in commentary (Schwenzer, 2008; Honnold, 1999) and in case law (Chinese Goods Case, 1996), the characteristics of force majeure event would still have to be evaluated through the requirements of article 79(1) CISG. This is due to the fact that unlike national laws, the CISG sets a very strict standard for exemption of liability, and the threshold is considered to be very high (Kröll et. al., 2011).

The first requirement for existence of an impediment which is beyond the control of the breaching party is relatively easily established. Namely, the existence of the impediment itself is a fact which can be easily verified, since earthquakes, wars, governmental sanctions are reported worldwide through media. Additionally, once the impediment is established as a fact is easily determinable that it is beyond the control of the parties since business parties cannot have an impact or control on wars, earthquakes and governmental sanctions. However, there might be some events which are considered to be force majeure, but over which the parties can have a control or at the very least an impact. For example, a general strike or boycott organized at state level, might be beyond the control of the contracting parties, however a strike or boycott organized at an industry branch level, or by one of the parties' own employees is certainly within the sphere of control or at the very least an event on which the affected party can have an impact.

The following two requirements are more problematic as there is a need for both objective and subjective assessment. The second requirement is that the event could not have been foreseen at the time of the conclusion of the contract. The "foreseeability" requirement contains geographical, historical as well as social perspectives. Namely, a certain event can be completely unforeseeable for one place or at one point in time and be completely normal and usual for another place or at another point in time. For example, while monsoons are common for South Asia, or fires are common for Australia, they are completely atypical for Europe. Similarly, wars and conflicts are typical for the past decades in the Middle East, while Canada has not had a war conflict on its territory for more than a century. In relation to commerce and governmental sanctions, in the past couple of years there had been a significant increase in trade wars compared to the past. In line with this, if a Chinese and a U.S. company have concluded a long-term contract 5 or 6 years ago, they could not have foreseen the outbreak of a trade war at the beginning of 2018. Thereby, depending on the geographical area, the place of business of the contracting parties as well as the socio-economic situation, one business party may be able claim exemption of liability due to a force majeure, while others would not be able to do so based on the same or similar circumstances.

Lastly, the breaching party has to prove that it could not have avoided or overcome the consequences of the impediment. This would mean that at the very least, the parties are obliged to show reasonable effort to overcome the effects of the impediment (Kröll et. al., 2011). For example, if the governmental sanctions are announced days in advance, then the seller should do everything in his power to deliver or dispatch the goods before the sanctions effectuate, 
even if that would mean paying higher prices for transport and forwarding. Comparably, the destruction of generic goods due to force majeure event would not release the reseller from liability as long as there are quantities of the generic goods left, even at higher prices. However, the situation is different if the seller is also producing the goods. In similar fashion with the "foreseeability" requirement, the conclusion here should be made on a case by case analysis. Another important issue which should be considered, is the duration of the force majeure event -the defaulting party is exempted only for the duration of the impediment (Article 79(3)CISG). This means that breaches which have occurred prior or subsequent to the event cannot be exempted from liability. Finally, a party who is hindered from performing must notify the other party in reasonable manner about the impediment and its effect on the performance of the obligation. The notification is a formal requirement under article 79(4) CISG, but it also stems from the good faith principle embodied in Article 7(2) CISG (Kröll et. al., 2011).

When applying the legal rules on the current COVID-19 pandemic, the key issue is whether epidemics are considered force majeure events, and most importantly do they fall within the scope of article 79 CISG. Firstly, as evident from the long form of the ICC force majeure clause, epidemics are listed as an example of force majeure event (www.iccwbo.org). While this is not a definitive conclusion on the nature of epidemics, it is indicative that some forms of epidemics can be considered force majeure events, given their magnitude and effect on international trade. Taking this into consideration, COVID-19 is a worldwide pandemic, which has resulted in 400,000+ deaths so far and has led to preventive measures that have shut down factories, borders, seaports and airports. The number of victims and the preventive measures which have been taken so far on a global scale can hardly be matched to any epidemic within the last 50 years.

In light of the CISG, there is no explicit reference that epidemics fall within article 79, neither in the Secretariat Commentary, nor in the Advisory Council Opinion No. 7. In these instances, case law provides guidance. In one case (L-lysine case, 2005) the respondent pleaded exemption of liability for failure to deliver connected to the 2002/2003 Severe Acute Respiratory Syndrome ("SARS") epidemic, which he qualified as force majeure. While the tribunal rejected the plea, it was due to the fact that the contract was concluded after the outbreak of the virus. The tribunal, as well as both parties accepted the notion that SARS constitutes a force majeure event.

In relation to the requirements of article 79(1) CISG, COVID-19 satisfies the first requirement, since there is no doubt that it is an impediment outside of the sphere of control of either of the parties which can hinder contract performance. In relation to the second requirement, unless the contract has been concluded after the proclamation of pandemic on global scale, it is very likely that the effects which the virus could not have been foreseen by the parties. A point for debate might be the period between the outbreak of the virus in China at the beginning of January, or the peak in China which was registered mid-February (www.worldometer.info), and the proclamation of worldwide epidemic. However, unless one of the contracting parties is from China, or supplies the goods directly from China, it is unlikely that the magnitude of the pandemic could have been foreseen, bearing in mind the unique features of the virus which also leave medical scientists and professionals perplexed.

The most difficult requirement for the exemption of liability is the inability to overcome the impediment caused by COVID-19, or its consequences. Namely, while governments have imposed drastic measures for the prevention of the spread of COVID-19, these restrictions were more lenient when it comes to trade. For example, most of the borders, ports and airports have been completely closed for transport of passengers, but remain open for transport of goods. Similarly, universities, schools and kindergartens are shut down while many factories remain open (albeit with reduced capacity). In light of this, unless the measures prevent either of the parties directly in performing the contract, it may be that the requirements of Art. 79(1) 
CISG are not met. This raises the question whether commercial parties are truly unable to overcome the impediment or its consequences, or are they simply put in more difficult situation. For example, if the seller's business operation has been shut down as a result of governmental measures, then he would be able to claim inability to overcome the impediment. On the contrary, if the seller is buying and reselling goods from multiple factories, and is operating only as a reseller in the supply chain, he would not be able to claim inability to overcome the impediment or its consequences if one of the factories is shut down, even if that puts him in more difficult situation. If the goods are generic, he might not be able to claim inability if all of his own suppliers are shut down, as long as there are factories, or sources from where he could obtain goods, regardless of the fact that there will be significant price increase. In China, the China Council for the Promotion of International Trade (CCPIT), a quasigovernment trade body, upon request of businesses, can issue a document which certifies inability of contract performance, which serve as a force majeure certificate. Only in the first weeks of February CCPIT has issued 3,325 force majeure certificates, with total contracts value of US\$38.4 billion (www.scmp.com). While these certificates have significance in proving inability for performance, in the absence of their uniform acceptance throughout the world, in international disputes they should serve only as prima facie evidence and not a definite proof for exemption of liability.

Given the fact that business parties might be faced with various impediments as a result of different measures imposed by the countries where they conduct their business, it has to be evaluated on a case by case basis whether the impediment would qualify as a force majeure event which makes contract performance impossible, or as an event which makes contract performance more difficult. While impossibility for contract performance leads to exemption of liability under article 79 CISG, the effects of changed circumstances which make contract performance more onerous will be discussed below.

\section{HARDHSIP}

Hardship is defined as something that causes or entails suffering or privation (www.merraimwebster.com). In legal terms, hardship is change in the circumstances which occurs after the conclusion of the contract, which is independent of the will of the parties and makes the performance of the contract on one or both of the parties more burdensome. The theory of hardship is widely accepted in the legal systems in continental Europe (Schwenzer \& Schlechtriem, 2010). The U.S. and the U.K. accept the notion of frustration of purpose - which is a type of change of circumstances where the contract purpose is rendered useless (Schwenzer, 2008). Whereas the continental systems are more focused towards the difficulty in performing an obligation, the common law systems assess the situation form the perspective of the purpose which the parties had prior to entering into contractual relation.

When it comes to the CISG, similarly like the concept of force majeure, hardship is not explicitly mentioned. On the other hand, the UNIDROIT Principles, which are very often used to supplement gaps within the CISG (Gotanda, 2007), contain detailed article which pertains to hardship. According to article 6.2.2 of the UNIDROIT Principles (2016) hardship exists when the occurrence of event "fundamentally alters the equilibrium of the contract either because the cost of a party's performance has increased or because the value of the performance a party receives has diminished." Additionally, Article 6.2.2. sets 3 prerequisites which need to be met: firstly, the event must have occurred or become known to the disadvantaged party after the conclusion of the contract, secondly, the event could not have been reasonably taken into account by the parties at the time of the conclusion of the contract, and thirdly, the event is beyond the control of the disadvantaged party (UNIDROIT Principles Article 6.2.2.). The ICC also has a model hardship clause which contains similar prerequisites (www.iccwbo.com). Some examples of hardship would be sharp increase in price in relatively stable market, 
imposition of duties, excessive tariffs or quotas for certain products, escalation of currency exchange rate beyond certain margins etc.

Unlike force majeure events which render contract performance impossible, the difference in hardship events is that the performance of the obligation is still possible, however it is excessively burdensome and onerous for the affected party. When considered, the prerequisites for both force majeure and hardship bear resemblance. Because of that, some authors (Schwenzer, 2008) consider hardship events as special group which falls within the more general sphere of force majeure. However, there seems to be functional difference between the two concepts generated through their different effects. While the effect of force majeure is contract termination or contract postponement (if applicable), the effect of hardship event is primarily contract renegotiation, adaptation and in the last instance termination. According to Rimke (1999) hardship is the reason for the change in the contractual program of the parties, since even in those circumstances the aim of the parties remains to implement the contract. According to Article 6.2.3 of the UNIDROIT Principles, the occurrence of hardship event gives the affected party the right to request renegotiations. This is the principal right in case of hardship. However, the request for renegotiations cannot itself serve as an entitlement to withhold performance. In case the negotiations fail, then either of the parties may resort to court or arbitration, and only the court or arbitral tribunal may further terminate or adapt the contract. Unlike force majeure, where contract termination is the most viable option, the main goal in situation of hardship is to keep the contract alive by restoring its equilibrium. This can be done either voluntarily by the parties through negotiations, or involuntarily by courts and arbitral tribunals through the remedy of adaption. Contract termination is remedy of last resort. While the traditional view was that hardship events do not fall within the scope of the CISG, this rigid stance has been slowly amended by authors who support the position that "impediment" within Article 79 can also encompass hardship events (Honnold, 1999; Schwenzer, 2008). The same progression of interpretation has also been evident in CISG case law (Nuova Fucinati v. Fondmetall International, 1993; Scafom International BV v. Lorraine Tubes S.A.S., 2009). The prerequisites listed under article 79 CISG are similar to the prerequisites for hardship accepted in other legal texts. In light with this, the question which remains is not whether events which make the contract performance more onerous can be considered as impediments under article 79 CISG, but rather how much more onerous the contract performance has to become in order for the affected party to be exempted from liability.

It is clear that not any event which makes the performance more burdensome would qualify. From the plain wording of various legal texts, it is evident that the event, or more specifically its consequences, have to be of magnitude which either makes contract performance excessively more onerous (PECL, Article 6:111), or fundamentally alters the equilibrium of the contract (UNIDROIT Principles, Article 6.2.2). Still, wording like this does not give definite answer what the threshold for hardship should be. While the commentary of article 6.2.2 of the 1994 version of the UNIDROIT Principles suggested 50\% contract alteration as a benchmark for hardship (UNIDROIT Principles 1994, Article 6.2.2.), from the 2004 version onwards, the practice for recommending a figure has been abandoned. Some authors (Brunner, 2009) have suggested that a threshold of $100 \%$ change should be taken as a general rule of thumb. However, a definite answer might not be merely impossible, but also inadvisable.

Even if we take the $100 \%$ threshold as standard for ordinary circumstances, in some specific cases lowering it or rising it would be necessary. For example, the Appellate court in Hamburg did not exempt the seller from liability under article 79 CISG, despite the fact that the price of the goods had risen by 300 percent (Iron molybdenum case, 1997). The court considered that due to the speculative nature of the market for the goods in question, the threshold for hardship should be raised. On the other hand, in relatively stable markets, even increase of $10-15 \%$ can 
be considered as sufficient especially if the contract has small profit margin. Another factor for decrease of the threshold for hardship may be a situation where the affected party is facing financial ruin. Consequently, where the threshold would be set has to be determined on a case by case analysis.

The prerequisites for exemption of liability for hardship under article 79(1) CISG would be identical with the requirements for exemption of liability for force majeure. The only difference regarding the conditions would be that under the concept of force majeure the affected party would have to plead that contract performance is impossible, whereas under the concept of hardship the affected party would have to prove that while performance is not impossible it is excessively more difficult. Additionally, although both force majeure and hardship would lead to exemption of liability for damages, the possible outcome of both concepts differs. Namely, the only viable remedy for force majeure is contract termination, whereas in cases of hardship renegotiation and adaptation have precedence over contract termination.

\section{CONCLUSION}

In light of the elaborated, the question which remains is whether COVID-19 can be considered a force majeure or a hardship event. Given the character of the pandemic and the various ways in which it can affect a contractual relationship, definite qualification cannot be given a priori, but rather a case by case analysis has to be conducted. While there are cases where contractual obligation might become impossible to fulfill due to COVID-19, it seems more likely that majority of the affected parties would only have difficulty in performing their obligations. Even in those cases where performance becomes impossible, it is probable that the impediment would be only temporary due to the nature of the virus.

In any case, parties in international transactions would have to carefully examine and evaluate both the factual and legal situation before they act. The first step in the legal evaluation is always to turn to the contract and see whether the parties have agreed on a clause regulating unforeseen events, such as force majeure or hardship. If they have done so, it is relevant to see if they have actually considered a pandemic or epidemy as an event which may disrupt the contractual relationship. If the parties have not implemented a limitation of liability as a contractual clause, then it has to be determined whether it has been done so through the applicability of the standard terms and conditions of either of the parties.

In absence of any contractual clause between the parties, the applicable law takes precedence. Here, it is very likely that the CISG would apply as a default law even if the parties have not chosen it, as long as they have not explicitly excluded its application. This is due to the fact that the CISG can be applied as a default law if the parties have places of business in contracting states, if the parties have chosen a law of a contracting state or if the conflict of law rules lead to the application of a law of a contracting state. Under the scope of the CISG exemption of liability is dependent on the fulfillment of several prerequisites listed in Article 79(1). The existence of those prerequisites to some extend might even undermine the classification of the impediment as force majeure of hardship in relation to exemption of liability for damages. However, the classification becomes necessary when we evaluate the remedies which would be at parties' disposal. In any case, while the selected approach is the party's strategic choice, it will be dependent on the objective factual situation. Namely, if the party is directly affected by the pandemic (e.g. factory ceases production due to governmental decision, governmental decision changes production lines, or factory shuts down due to spread of virus among employees), then it would be reasonable to argue force majeure, whereas if the party is indirectly affected (e.g. one of its suppliers has ceased production, transport has become more expensive due to lack of transporters and quarantine periods) it is more likely to plead hardship. However, in cases of hardship the establishment of the threshold for impediment, and more importantly proving that the impediment is above the threshold becomes crucial. 
Another important aspect, especially in cases of pandemic is the time factor on performance. If timely performance of the obligation is of essence, then using remedy different from termination might be superfluous. In all other cases suspension of the contract for the duration of the impediment or renegotiation of contract terms would be more feasible. In light with this, the CISG exempts the affected party from liability only for the duration of the impediment (Article 79(3) CISG). This approach prevents parties from taking advantage of the situation and using it either to gain more profit or to get out form a bad deal.

Finally, regardless of which approach is taken by the affected party, it is always necessary that the opposing party is notified for the impediment. Timely communication is of utmost importance in international trade, and in period of turmoil it becomes even more crucial. Informing the counterparty helps mitigate losses, especially in supply chains where the default of one supplier might lead to disruption of the whole chain.

\section{REFERENCES}

Brunner, C. (2009), Force Majeure And Hardship Under General Contract Principles: Exemption of Non-Performance in International Arbitration. Kluwer Law International, The Hague, The Netherlands.

Belgian Supreme Court (2009), "Scafom International BV v. Lorraine Tubes S.A.S ”. available at: http://cisgw3.law.pace.edu/cases/090619b1.html (accessed 03 June 2020).

CIETAC - China International Economic and Trade Arbitration Commission, (2005), "LLysine case", available at: http://cisgw3.law.pace.edu/cases/050305c1.html. (accessed 30 May 2020).

CISG-AC Opinion No. 7 (2007), "Exemption of Liability for Damages under Article 79 of the CISG", Adopted by the CISG-AC at its 11th meeting in Wuhan, People's Republic of China on 12 October 2007.

Gotanda, J. (2008), Using the UNIDROIT Principles to Fill Gaps in the CISG. Hart Publishing, Portland, OG.

Hamburg District Court (1996), "Chinese Goods Case", available at: http://cisgw3.law.pace.edu/cases/960321g1.html/ (accessed 29 May 2020).

Hamburg Appellate Court, (1997) "Iron molybdenum case", available at: http://cisgw3.law.pace.edu/cases/970228g1.html/ (accessed 30 May 2020).

Honnold, J. (1999), Uniform Law for International Sales Under The 1980 United Nations Convention, Kluwer Law International, The Hague, The Netherlands.

ICC - International Chamber of Commerce (2020), "ICC Force Majeure And Hardship Clauses - ICC - International Chamber of Commerce", available at: https://iccwbo.org/publication/iccforce-majeure-and-hardship-clauses (accessed 28 May 2020).

Klotz, J. and Barrett, J. (2008), International Sales Agreements. Kluwer Law International, Alphen aan den Rijn, The Netherlands.

Kocev, Lj. (2018), "Scope of application of the "United Nations Convention on Contracts for the International Sale of Goods (CISG)" in international trade, Annual of Faculty of Economics - Skopje, vol. 53, 187-201.

Kröll, S. and Mistelis, L., (2011), UN-Convention on The International Sales of Goods (CISG), Beck Publishing, Munich, Germany.

Legal Information Institute (2020), "Definition of Force Majeure", available at: https://www.law.cornell.edu/wex/force majeure (accessed 3 June 2020).

Lookofsky, J. (2012), Convention on Contracts for The International Sale of Goods (CISG), Kluwer Law International, The Hague, The Netherlands.

Merriam Webster Dictionary (2020), "Definition of Hardship", available at: https://www.merriam-webster.com/dictionary/hardship (accessed 7 June 2020). 
Monza District Court (1993), "Nuova Fucinati v. Fondmetall International" , available at: http://cisgw3.law.pace.edu/cases/930114i3.html (accessed 03 June 2020).

OECD - Organization for Economic Cooperation and Development (2020), "COVID-19 And International Trade: Issues and Actions." available at: http://www.oecd.org/coronavirus/policy-responses/covid-19-and-international-trade-issuesand-actions-494da2fa/. (accessed 28 May 2020).

PECL - Principles of European Contract Law, (2002).

Rimke J. (1999), Force majeure and hardship: Application in international trade practice with specific regard to the CISG and the UNIDROIT Principles of International Commercial Contracts - Review of The Convention on Contracts for the International Sale of Goods (CISG), Kluwer Law International, The Hague, The Netherlands.

Schwenzer I. (2007), "Force Majeure and Hardship in International Sales Contracts". Victoria University of Wellington Law Review Vol.39, No. 4, 709-726.

Schwenzer, I. and Schlechtriem, P. (2010), Commentary on The UN Convention On The International Sale Of Goods (CISG). Oxford University Press, Oxford, UK.

South China Morning Post (2020), "Can Chinese Firms Invoke Force Majeure As Coronavirus Outbreak Rages On?", available at: https://www.scmp.com/economy/chinaeconomy/article/3052277/coronavirus-doubts-raised-over-whether-chinese-companies-can (accessed 6 June 2020).

UNIDROIT Principles of International Commercial Contracts (2016).

United Nations Convention of Contracts for the International Sale of Goods, (1980).

UNCITAL - United Nations Commission on International Trade Law (2020). "Status: United Nations Convention on Contracts for The International Sale of Goods (Vienna, 1980) (CISG)", available at: https://uncitral.un.org/en/texts/salegoods/conventions/sale of goods/cisg/status (accessed 2 June 2020).

WHO - World Health Organization (2020), "Coronavirus Disease (COVID-19) - Events as They Happen", available at: https://www.who.int/emergencies/diseases/novel-coronavirus2019/events-as-they-happen (accessed 27 May 2020).

Worldometer Info (2020), "China Coronavirus: 83,030 Cases And 4,634 Deaths Worldometer", available at: https://www.worldometers.info/coronavirus/country/china/ (accessed 6 June 2020).

WTO - World Trade Organization (2020), "Trade Set to Plunge As COVID-19 Pandemic Upends Global Economy" available at: https://www.wto.org/english/news_e/pres20_e/pr855_e.htm (accessed 28 May 2020). 